MINERALOGIA, 49, No 1-4: 17-34 (2018)

DE DE GRUYTER

DOI: 10.2478/mipo-2018-0003

www.Mineralogia.pl

Mineralogical SOCIETY of Poland

PolskiE TOWARZYSTWO MINERALOGICZNE

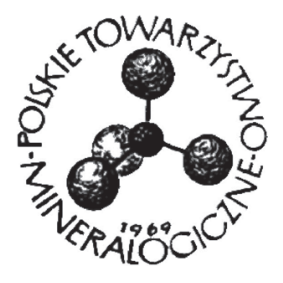

Original paper

\title{
Polymetamorphic evolution of pelites inferred from tourmaline zoning - the Rędziny hornfels case study at the eastern contact of the Karkonosze Granite, Sudetes, Poland
}

\author{
Jarosław Majka ${ }^{1,2, *}$, Mateusz P. Sęk ${ }^{1}$, Stanisław Mazur ${ }^{3}$, Bożena Gołębiowska ${ }^{1}$, \\ Adam Pieczka ${ }^{1}$ \\ ${ }^{1}$ AGH University of Science and Technology, Department of Mineralogy, Petrography and Geochemistry, \\ Mickiewicza 30, 30-052 Kraków, Poland \\ ${ }^{2}$ Uppsala University, Department of Earth Sciences, Villavägen 16, SE-752 36 Uppsala, Sweden, \\ ${ }^{3}$ Polish Academy of Sciences, Institute of Geological Sciences, Senacka 1, 31-002 Kraków, Poland \\ * Corresponding author \\ e-mail: jaroslaw.majka@geo.uu.se
}

Received: April 20, 2017

Received in revised form: August 30, 2017

Accepted: December 10, 2017

Available online: April 10, 2018

Abstract. Tourmaline occurring in hornfelses from the eastern envelope of the Karkonosze Granite (Western Sudetes, Poland) reveals at least two stages of crystallization expressed by its complex zoning. The cores and mantles of the crystals probably grew during prograde metamorphism under intermediate pressure-temperature conditions reflected by increasing $\mathrm{Mg}$, $\mathrm{Ti}$ and $\mathrm{Ca}$. Outermost rims show enrichment in $\mathrm{Al}$ and $\mathrm{Ca}$, indicating growth during contact metamorphism in the presence of an Al-saturating phase. The Ti-content in biotite indicates that the temperature of the contact metamorphic event did not exceed $650^{\circ} \mathrm{C}$. The presence of andalusite and the lack of garnet and cordierite also indicates pressure conditions of $\sim 2-3 \mathrm{kbar}$, typical of the $\mathrm{C} 1$ bathozone of Carmichael (1978) or the P1 bathozone of Pattison (2001).

Key-words: contact metamorphism, tourmaline, Ti-in biotite, Karkonosze-Izera Massif, Bohemian Massif

\section{Introduction}

Tourmaline is a group of minerals with a highly diversified composition whose chemical formulae can be written as $X_{3} Z_{6}\left[T_{6} O_{18}\right]\left[\mathrm{BO}_{3}\right]_{3} V_{3} W$ (Henry et al. 2010), where the letters denote: $X-\mathrm{Na}^{+}, \mathrm{K}^{+}, \mathrm{Ca}^{2+}$ and vacancy $[\square] ; Y-\mathrm{Li}^{+}, \mathrm{Mg}^{2+}, \mathrm{Fe}^{2+}, \mathrm{Mn}^{2+}, \mathrm{Zn}^{2+}$, 
$\mathrm{Al}^{3+}, \mathrm{Cr}^{3+}, \mathrm{V}^{3+}, \mathrm{Fe}^{3+}, \mathrm{Ti}^{4+} ; Z-\mathrm{Mg}^{2+}, \mathrm{Al}^{3+}, \mathrm{Cr}^{3+}, \mathrm{V}^{3+}, \mathrm{Fe}^{3+}, \mathrm{Ti}^{4+} ; T-\mathrm{Si}^{4+}, \mathrm{Al}^{3+}, \mathrm{B}^{3+} ; B-\mathrm{B}^{3+} ;$ $V-\mathrm{OH}^{-}, \mathrm{O}^{2-}$ and $W-\mathrm{OH}^{-}, \mathrm{F}^{-}, \mathrm{O}^{2-}$. The wide pressure-temperature $(\mathrm{P}-\mathrm{T})$ stability field and complex structure of tourmaline provides a unique opportunity to use this mineral as a good petrogenetic indicator (Henry, Guidotti 1985). In pelitic schists subjected to polymetamorphism, chemical zoning patterns in tourmaline give particularly valuable information on their history.

The crystallization of tourmaline in pelitic rocks can commence at the beginning of burial in a zone of advanced diagenesis and progress continuously under moderate- to highgrade metamorphic conditions (e.g. Henry, Dutrow 1996). Tourmalines are also known from LP-HT environments and hydrothermal ore deposits. In the latter case, the appearance of tourmaline often pre-dates the main stage of ore deposit formation (Pirajno 1992).

This paper describes the complexity of tourmaline internal zoning in the hornfels from Rędziny in the eastern contact aureole of the Karkonosze Granite, Sudetes. This rock underwent regional metamorphism and was subsequently overprinted by contact metamorphism caused by the emplacement of the Karkonosze Granite. The aim of the paper is to define the correlation between the chemical zoning of the tourmaline and the multistage metamorphic history of the host rock. The P-T conditions associated with the final stage of the tourmaline crystallization are also estimated.

\section{Geological setting}

The eastern margin of the Karkonosze-Izera Massif is a longitudinal metamorphic belt located between the Variscan Karkonosze Pluton to the west and the CarboniferousPermian Intrasudetic basin to the east (Fig. 1a, b). It consists mainly of gneisses, mica schists and metabasites that have been previously considered:

1. A stratigraphically uniform early Palaeozoic sequence (Berg 1912; Maška 1954; Teisseyre 1971, 1973).

2. An assemblage of a few distinct units of Precambrian and early Palaeozoic age, separated by unconformities (Chaloupský 1965, 1989) or tectonic contacts (Kodym, Svoboda 1948; Oberc 1960; Szałamacha, Szałamacha 1968; Mazur 1995; Kryza, Mazur 1995).

Following the classical stratigraphic scheme of Teisseyre (1971, 1973), Kryza and Mazur (1995) subdivided the eastern margin of the Karkonosze-Izera Massif into a number lithostratigraphic units:

1. The Kowary Gneiss Group (gneisses with thin intercalations of mica schists; Lower Allochthon in Figure 1b).

2. The Czarnów Schist Formation (mica schists, banded amphibolites and quartzofeldspathic rocks with minor marbles, reaction skarns and graphite schists; Lower Allochthon in Figure 1b).

3. The Niedamirów Schist Formation (greenstones, phyllites; Middle Allochthon in Figure 1b).

4. The Leszczyniec Meta-igneous Complex (mafic and felsic metavolcanic rocks and trondhjemitic gneisses; Leszczyniec Unit in Figure 1b). 

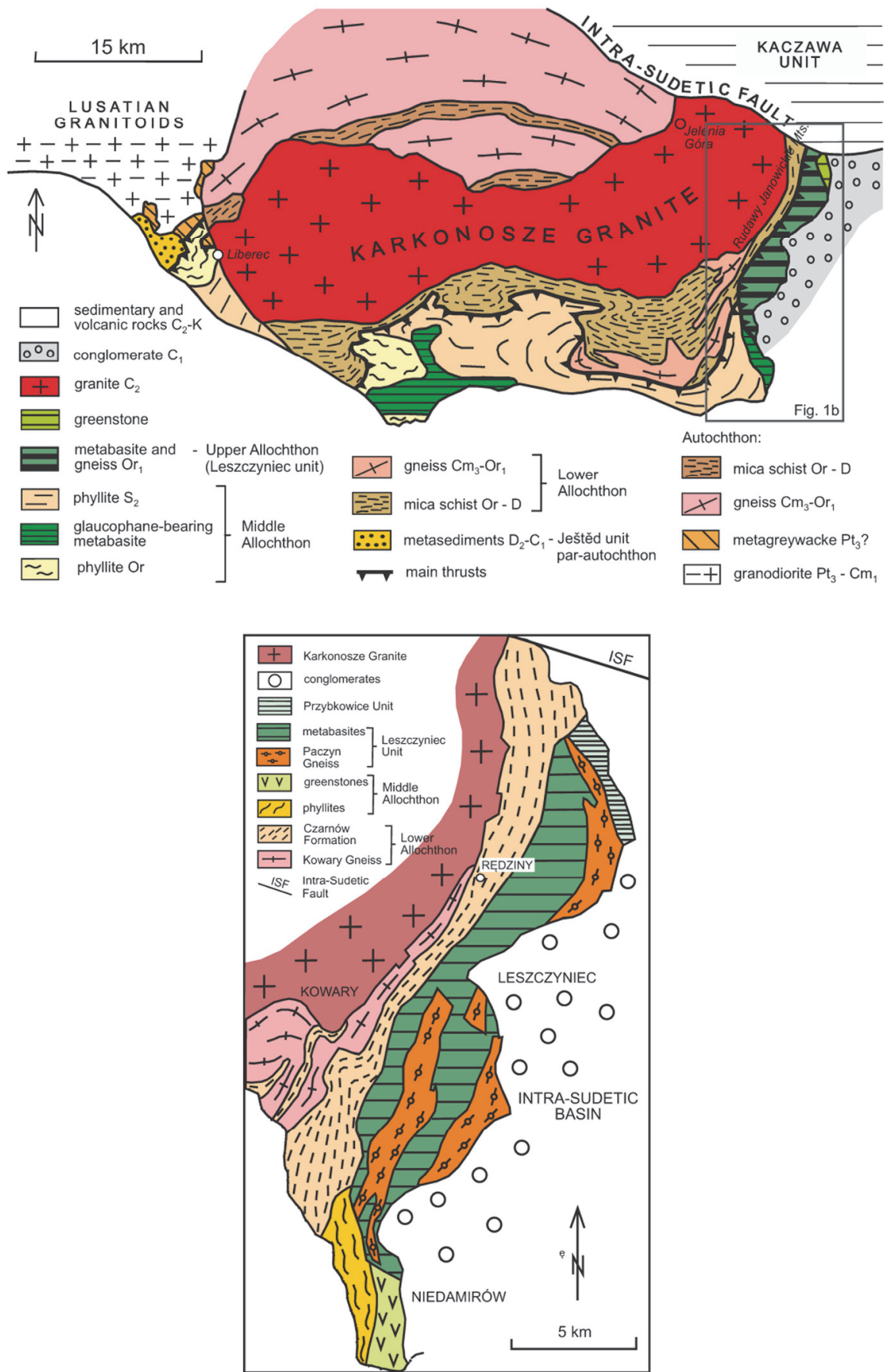

Fig. 1. Geological sketch maps of (a) the Karkonosze-Izera Massif and (b) the eastern metamorphic envelope of the Karkonosze Granite with the Rędziny locality marked. Both maps are modified after Mazur (1995). 
The Kowary Gneiss Group and the Czarnów Schist Formation have been interpreted to represent the parautochthonous early Palaeozoic continental crust of the Saxothuringian terrane (Mazur 1995; Mazur, Aleksandrowski 2001). However, according to the revised tectono-stratigraphic scheme (Žáčková et al. 2010; Jeřábek et al. 2016; Majka et al. 2016), the Czarnów Schist Formation belongs the lowermost allochthonous unit derived from the Saxothuringian basement. The protolith of the Kowary Gneiss has been geochronologically dated as of latest Cambrian - earliest Ordovician age [492-481 Ma, Oliver et al. (1993) and $487 \pm 8$ Ma, Oberc-Dziedzic et al. (2010)]. The quartzofeldspathic schists, despite being intercalated within the Kowary gneiss, show a sedimentation age of ca $500 \mathrm{Ma}$ that is similar to the emplacement age of the neighbouring gneiss (Oberc-Dziedzic et al. 2010). This is indicative of a tectonic contact between the gneiss and the schists and implies the occurrence of thrusts within the Kowary Group as well as between the Kowary Group and the Czarnów Formation ( $c f$. Seston et al. 2000).

The tectonic evolution of the eastern Karkonosze-Izera Massif involved two main events related to contraction and subsequent extension of the continental crust (Mazur 1995; Mazur, Kryza 1996). The contractional event, latest Devonian to early Carboniferous in age (Žáčková et al. 2010; Jeřábek et al. 2016), comprised pervasive reverse-displacement shearing, associated with NW-directed thrusting and concomitant progressive metamorphism, which resulted in tectonic juxtaposition of the thrust units (Mazur, Aleksandrowski 2001). This event produced a widespread deformational fabric consisting of the main foliation and a mostly NW-SE trending stretching lineation with localized presence of top-to-the NW shear criteria. The subsequent extensional event of early Carboniferous age comprised normal to wrench-normal shearing related to ESE-directed extensional collapse (Mazur 1995). The extensional displacements were localised in a several kilometres wide dip-slip shear zone along the eastern margin of the KarkonoszeIzera Massif. This N-S trending zone corresponds to the outcrop of the Czarnów Formation, which defines a narrow belt east of the Karkonosze Pluton.

Teisseyre (1973) interpreted the Czarnów Formation to represent conditions transitional between the Qtz-Ab-Ep-Alm zone of the greenschist facies and the almandine-amphibolite facies. He also delineated metamorphic mineral zonation within a few hundred-metre-thick Karkonosze Granite contact aureole. According to Kryza and Mazur (1995), the Kowary Group and Czarnów Formation experienced metamorphic paths from medium pressure conditions (probably below the amphibolite facies) to temperature-dominated metamorphism. The latter may have been contemporaneous or have preceded the Karkonosze Granite intrusion. Such a metamorphic sequence is additionally evidenced by the garnet zonation in the Kowary mica schists, with increasing Alm content from core to rim (Kryza, Mazur 1995).

The timing of the high-temperature event in the Czarnów Formation is constrained by the age of the Karkonosze Granite. High-precision CA-ID-TIMS zircon ages provide evidence that the crystallization of the two main granite facies, porphyritic and equigranular, happened between $312.5 \pm 0.3$ and $312.2 \pm 0.3 \mathrm{Ma}$ (Kryza et al. 2014). Only a slightly older time span of ca 320-315 Ma for the granite emplacement was obtained by Žák et al. (2013), who dated a broader variety of granite facies using the laser ablation ICPMS technique. The latter results are comparable to the zircon SHRIMP ages of $318.5 \pm 3.7$ 
Ma, 314.9 4 4.5 Ma and 314.1 \pm 3.3 Ma obtained by Machowiak and Armstrong (2007) for three distinct types of the Karkonosze granite.

\section{Petrography of the Rędziny hornfels}

Hornfelses cropping out in the Rędziny quarry are thermally metamorphosed mica schists of the Czarnów Formation. They are mainly composed of quartz, K-feldspar, dark mica, muscovite, rare plagioclase and andalusite. The structural relic of pre-contact metamorphism evolution of the hornfels is a foliation underlined by thin alternating quartz (with minor plagioclase) and phyllosilicate layers. The latter contain abundant dark mica and muscovite. Notably, dark mica is much more common in the form of unequivocally post-kinematic, relatively large flakes which are oblique to the foliation. In contrast, muscovite forms only small, partially dismembered flakes within the foliation planes. The most visible effects of the contact metamorphic overprint are development of the euhedral and post-kinematic dark mica noted above and the re-arrangement of quartz into polygonalshaped crystals. Besides the transversal dark mica, newly formed phases are K-feldspar and irregularly shaped andalusite. Both, K-feldspar and andalusite probably grew as a result of the muscovite decomposition reaction (Winkler 1979). Although cordierite was not found, small pinitic pseudomorphs after an unknown mineral are occasionally seen scattered in the rock. The most abundant accessory phase is tourmaline with complex zoning (Fig. 2). It is commonly intergrown with the second generation of biotite (Fig. 2). Besides tourmaline, rutile, ilmenite, graphite and other opaque minerals occur.

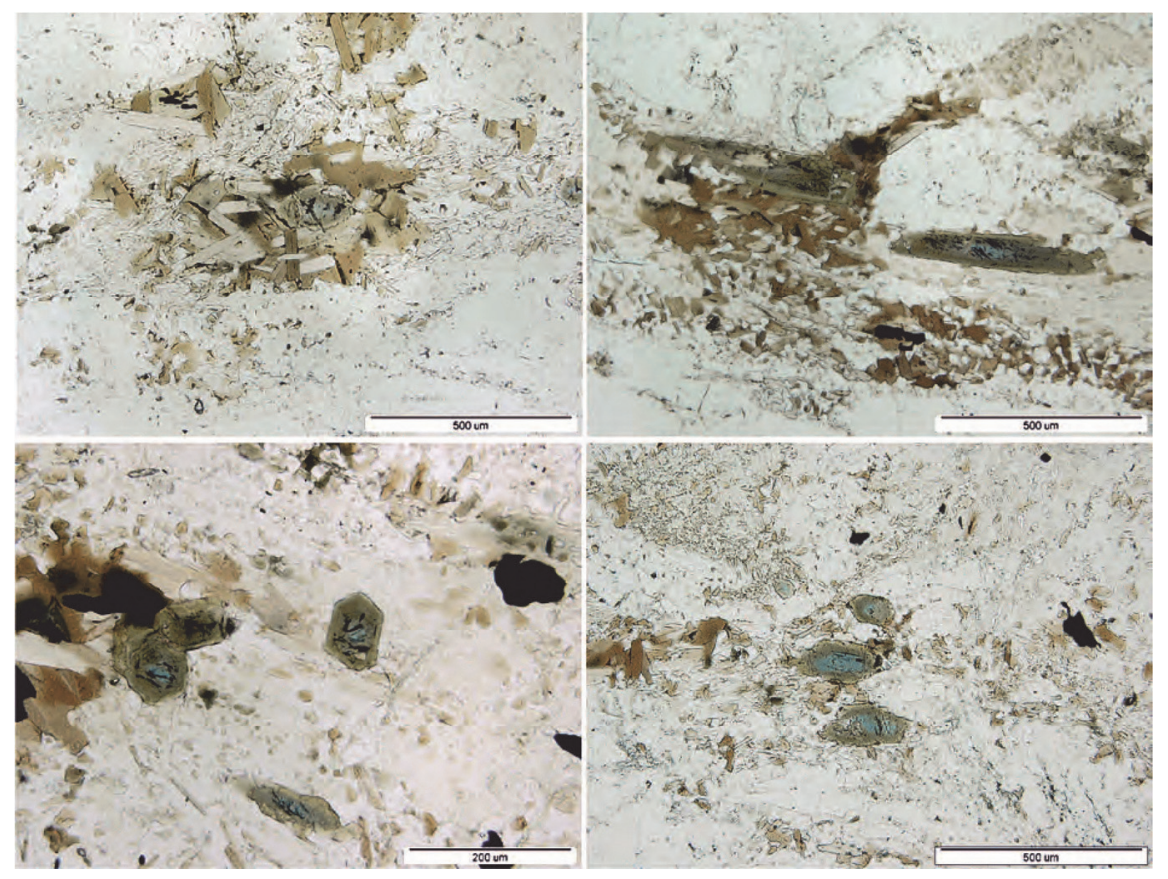

Fig. 2. Photmicrographs (1N) of tourmalines and biotites in the Rędziny hornfels. 


\section{Methods}

Electron microprobe analyses of tourmaline crystals were done at the Inter-Institute Analytical Complex for Minerals and Synthetic Substances of the Warsaw University with a CAMECA SX-100 electron microprobe operating in the wave-length-dispersive (WDS) mode under the following conditions: excitation voltage $15 \mathrm{kV}$, beam current $20 \mathrm{nA}$, beam diameter about $2 \mu \mathrm{m}$, peak count-time $20 \mathrm{~s}$, background time $10 \mathrm{~s}$. The standards, analytical

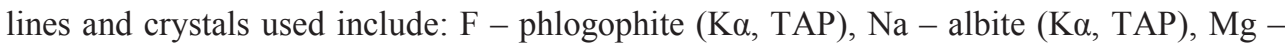

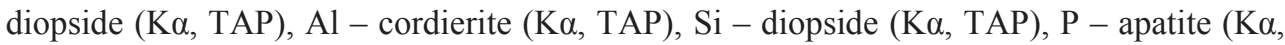

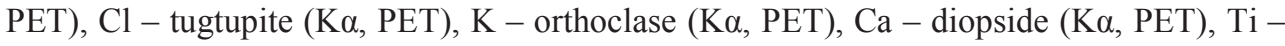

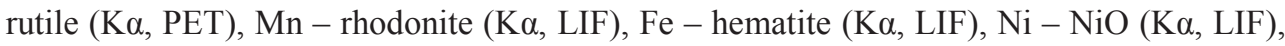

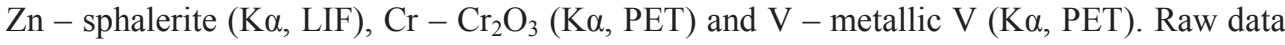
were corrected with the PAP procedure of Pouchou and Pichoir (1985).

The crystallochemical formulae of the tourmalines were normalized on the basis of 15 $\mathrm{Y}+\mathrm{Z}+\mathrm{T}$ atoms per formula unit (apfu) if, in the normalization $\mathrm{T} \leq 6 \mathrm{Si}$ apfu (external zones of crystals), or to $9 \mathrm{Y}+\mathrm{Z}$ apfu in the opposite case (internal zones of crystals), with $\mathrm{B}_{2} \mathrm{O}_{3}$ amounts calculated with the assumption of $3 \mathrm{~B}$ apfu, and $\mathrm{H}_{2} \mathrm{O}$ occurring in the form of $\mathrm{OH}$ groups calculated by stoichiometry. The used normalization option was conditioned by the tourmaline stoichiometry, i.e. complete occupancy of the $\mathrm{Y}, \mathrm{Z}$ and $\mathrm{T}$ sites, and the amount of $\mathrm{Si}$ not higher than 6 apfu. Excesses of $\mathrm{SiO}_{2}$, found only in inner zones of the crystals, were deemed to be tiny inclusions of quartz on the micro- to nano-scale.

\section{Crystal chemistry of tourmaline from Rędziny}

Microscopic observations in transmitted light show three general units in the crystals of tourmaline from Rędziny: (1) light blue cores, (2) olive green to brownish intermediate mantle zones and (3) light green rims. In the core and mantle tourmaline, there are numerous opaque inclusions of ilmenite; such are absent in the rim tourmaline (Fig. 2). In back-scattered-electron (BSE) images, the crystals show slightly more complex oscillatory zoning, with some clearly-visible sub-zones in the core- and rim tourmaline (Fig. 3; Table 1). The outermost rim, darkest in the BSE images, is discontinuous with visible tiny embayments into mantle tourmaline in some cases (Fig. 3c, d). However, the compositions of these tourmaline zones, plotted in the system $\mathrm{Fe}-\mathrm{Mg}-\mathrm{Al}$ in terms of the main octahedral occupants, plot only in two clearly distinguished clusters that might be related to the core + mantle and rim tourmaline (Fig. 4). Thus, the whole interior of the crystals, i.e., the bluish core and all overgrowing subzones of the olive brown mantle up to the outermost rim, have the same geochemical signature and can be related to a single crystallization episode with varying diffusion of the main components to the growing crystal. All the tourmalines are devoid of $\mathrm{Mn}, \mathrm{Zn}, \mathrm{V}, \mathrm{Cr}$ and $\mathrm{Ni}$, and their compositions may be examined in the system $\mathrm{Na}(\mathrm{K})-\mathrm{Ca}-\mathrm{Mg}-\mathrm{Fe}-\mathrm{Al}-\mathrm{Ti}-\mathrm{Si}-\mathrm{B}-\mathrm{O}-\mathrm{OH}-\mathrm{F}$. Statistics for the tourmaline compositional data in all the distinguished zones (core, 3 generalized mantle subzones distinct by the varying $\mathrm{Fe}, \mathrm{Mg}, \mathrm{Al}$ and $\mathrm{Ti}$, overgrowing oscillatory the core outward, and rim) are given in Table 1, whereas average compositions of tourmaline in these zones are presented in Table 2. As all the tourmalines have the $X$ site dominantly occupied with $\mathrm{Na}$, and the $W$ site occupied by $\mathrm{OH}^{-}, \mathrm{F}^{-}$and $\mathrm{O}^{2-}$, they represent solid solutions of hydroxy-, fluor- and oxy-species of the 
alkali-tourmaline group [for nomenclature of the tourmaline-supergroup minerals see Henry et al. (2010)]. However, the core- and mantle tourmaline have ${ }^{W}(\mathrm{OH}+\mathrm{F})>>{ }^{W} \mathrm{O}$ and therefore, at the subordinate $\mathrm{F}$, they represent hydroxy-tourmaline species, whereas the rim tourmaline with ${ }^{W} \mathrm{O}>0.50$ apfu $>{ }^{W}(\mathrm{OH}+\mathrm{F})$ represents an oxy-tourmaline species (Fig. 5). Compositional statistics indicate that, neglecting $\mathrm{Mg}-\mathrm{Al}$ and $\mathrm{Fe}^{2+}-\mathrm{Al}$ disorder between the $Y$ and $Z$ sites, $\mathrm{Mg}$ and $\mathrm{Fe}^{2+}$ are the main $Y$-site occupants in successive crystal zones from the core through the mantle subzones up to the rim tourmaline. This results in compositional fluctuation of the species from Mg-bearing schorl to Fe-bearing dravite in the core and mantle, and Fe-bearing oxy-dravite in the rim (Fig. 6a). The content of ${ }^{Y+Z} \mathrm{Al}$ oscillates around 6 apfu in the core and mantle tourmaline with a visible decreasing tendency from 6.33 to $5.73 \mathrm{apfu}$, but it suddenly increases up to $6.31-6.87 \mathrm{apfu}$ in the rim. The increase is caused by $\mathrm{Al}$ for $\mathrm{Y}^{2+}$ replacement, mainly for $\mathrm{Fe}^{2+}$ (Fig. 6b, c). Surpluses of Si in the core and mantle tourmaline of the order $0.05-0.15$ apfu over the ideal amount of $6 \mathrm{Si}$ apfu are considered to be quartz inclusions on the nanometer scale. In contrast, the Si content in the rim tourmaline is always slightly below 6 apfu, and must be filled up by $\mathrm{Al}$ in amounts reaching 0.27 apfu. Calcium and $\mathrm{Ti}$ are the only subordinate components that, apart from variation of $\mathrm{Mg}, \mathrm{Fe}^{2+}$ and $\mathrm{Al}$, differentiate tourmaline in the successive zones. Both are negligible in the crystal cores and reach 0.01-0.03 apfu. In the mantle- and rim zones, the Ti
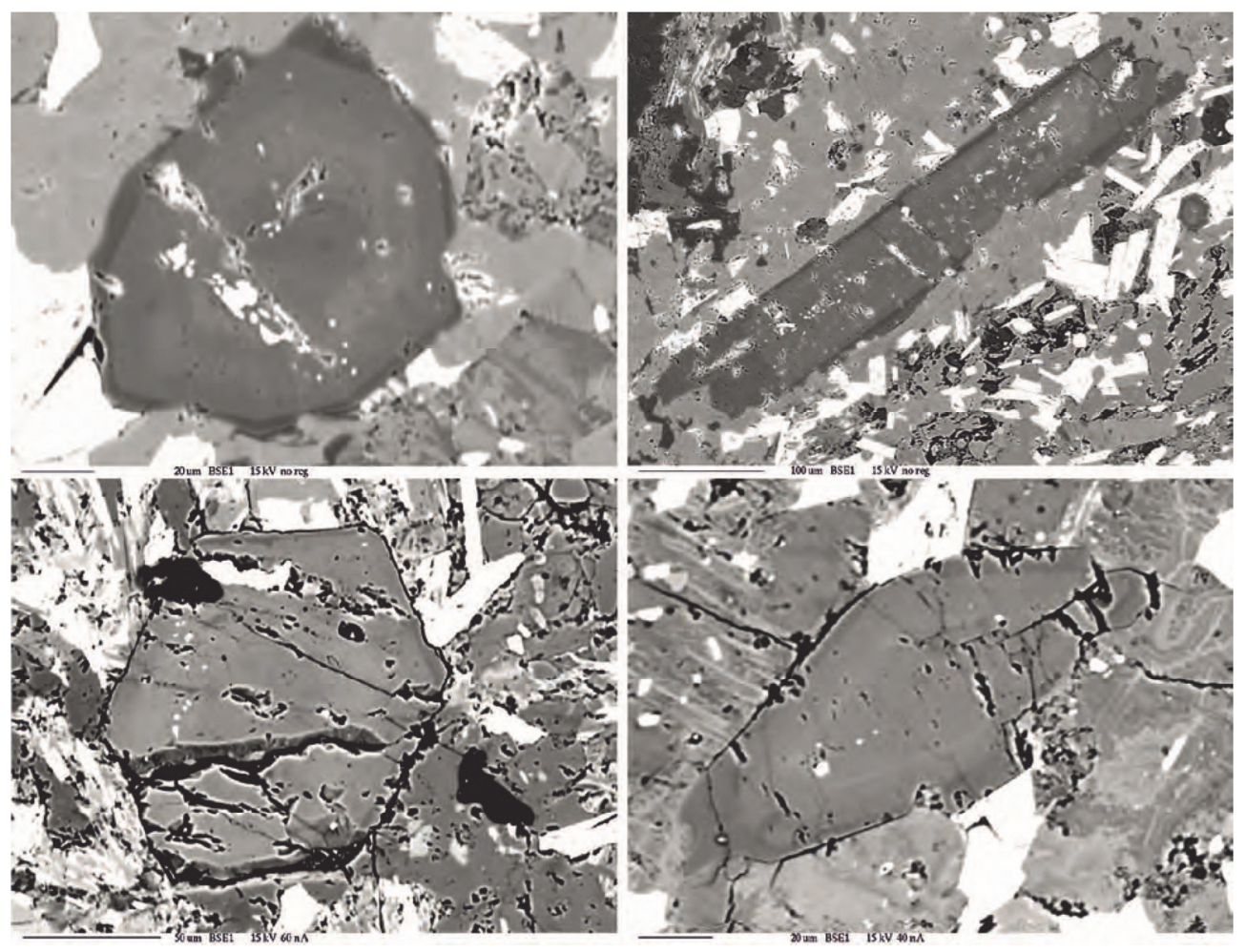

Fig. 3. BSE images of complex zoned tourmalines from the Rędziny hornfels. Up to 9 zones are visible. 


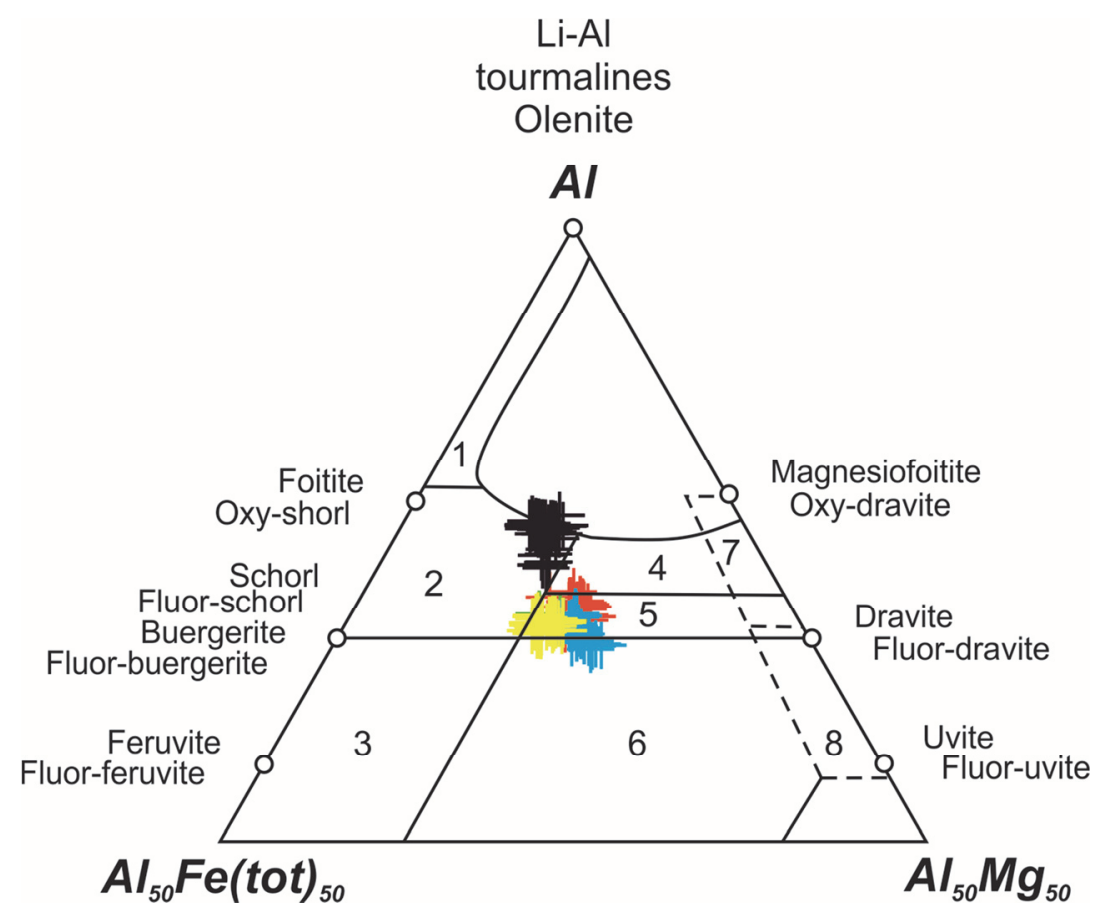

Fig. 4. Al-Fe-Mg ternary plot of Henry and Guidotti (1985) for tourmaline core, mantle and rim from the Rędziny hornfels. The core and mantle tourmalines lie in the field of metapelites and metapsammites not coexisting with an Al-saturating phase, whereas the rim tourmaline lies in the field of metapelites and metapsammites coexisting with an $\mathrm{Al}$ saturating phase. Symbols: black crosses - rim tourmaline; green, blue and yellow crosses - mantle tourmalines of the generalized subzones $1-3$, respectively; red crosses - core tourmaline.

content suddenly increases up to 0.17-0.18 apfu, and even to 0.25-0.30 apfu $\left(2.32 \mathrm{TiO}_{2}\right.$ wt.\%) in the nearest neighborhood of ilmenite inclusions. The straight relationships Ti vs ${ }^{Y+Z} \mathrm{Al}$ and $\mathrm{Mg}+\mathrm{Fe}$ vs ${ }^{Y+Z}\left(\mathrm{Al}+\mathrm{Ti}\right.$ ) (Fig. 6d, e) suggest simple Ti for ${ }^{Y+Z} \mathrm{Al}$ replacement in the core and rim tourmaline. Finally, the relationship ${ }^{W} \mathrm{O}$ vs ${ }^{Y+Z}(\mathrm{Al}+\mathrm{Ti}) /{ }^{Y+Z}(\mathrm{Al}+\mathrm{Mg}+\mathrm{Fe}+\mathrm{Ti})$ clearly separates the schorl-dravitic compositions of the core and mantle tourmaline from the rim tourmaline compositions, plotting in the oxy-dravitic and oxy-schorl field (Fig. 6f). Calcium increases progressively from a relatively low content of 0.01-0.02 apfu in the core tourmaline, up to 0.10-0.12 apfu in the outermost mantle subzone (3) and up to 0.17 apfu in the rim. Traces of $\mathrm{Ti}$ in the tourmaline rim are responsible for the dominance of $\mathrm{Fe}^{2+}{ }_{\mathrm{t} 2 \mathrm{~g}} \leftrightarrow$ $\mathrm{Fe}^{2+}{ }_{\text {eg }}$ and $\mathrm{Fe}^{2+} \leftrightarrow \mathrm{Fe}^{3+}$ electron transitions that induce an absorption band at around 14000 $\mathrm{cm}^{-1}(714 \mathrm{~nm})$ (da Fonseca-Zang et al. 2008) and generate the bluish colour of this tourmaline variety. In the mantle tourmaline, the Ti contents are much higher, which results in high abundances of $\mathrm{Fe}^{2+} \leftrightarrow \mathrm{Ti}^{4+}, \mathrm{Ti}^{3+} \leftrightarrow \mathrm{Ti}^{4+}$ or $\mathrm{Ti}^{3+} \leftrightarrow \mathrm{Ti}^{4+} \leftrightarrow \mathrm{Fe}^{3+}$ charge-transfer transitions with absorption around $24000 \mathrm{~cm}^{-1}(416 \mathrm{~nm})$ connected with various shades of brown. The light green rims reflect a coupled effect of intense absorption bands at 416 and $714 \mathrm{~nm}$. 
Chemical compositions of zoned tourmaline crystals from Rędziny (statistic data)

\begin{tabular}{|c|c|c|c|c|c|}
\hline $\begin{array}{l}\text { zone } \\
\text { wt. } \%\end{array}$ & $\begin{array}{c}\text { core } \\
n=23\end{array}$ & $\begin{array}{l}\text { mantle } 1 \\
n=8\end{array}$ & $\begin{array}{l}\text { mantle } 2 \\
n=23\end{array}$ & $\begin{array}{l}\text { mantle } 3 \\
n=27\end{array}$ & $\begin{array}{c}\text { rim } \\
n=37\end{array}$ \\
\hline $\mathrm{SiO}_{2}$ & $35.94-36.92$ & $36.29-36.61$ & $35.58-36.53$ & $36.03-36.73$ & $34.72-36.74$ \\
\hline $\mathrm{TiO}_{2}$ & $0.06-0.28$ & $0.46-1.36$ & $0.40-2.32$ & $0.40-1.44$ & $0.20-1.31$ \\
\hline $\mathrm{B}_{2} \mathrm{O}_{3 \text { (calc.) }}$ & $10.26-10.46$ & $10.25-10.39$ & $10.11-10.39$ & $10.27-10.49$ & $10.31-10.70$ \\
\hline $\mathrm{Al}_{2} \mathrm{O}_{3}$ & $30.30-31.99$ & $30.26-31.11$ & $28.43-30.92$ & $29.79-31.24$ & $33.15-36.09$ \\
\hline $\mathrm{FeO}$ & $8.39-10.86$ & $8.37-9.56$ & $9.48-11.40$ & $8.17-9.71$ & $5.81-7.58$ \\
\hline $\mathrm{MgO}$ & $5.26-6.07$ & $5.91-6.56$ & $5.17-6.10$ & $5.98-6.98$ & $4.66-5.89$ \\
\hline $\mathrm{CaO}$ & $0.00-0.14$ & $0.02-0.30$ & $0.06-0.25$ & $0.14-0.66$ & $0.32-0.96$ \\
\hline $\mathrm{Na}_{2} \mathrm{O}$ & $2.38-2.80$ & $2.51-2.82$ & $2.55-2.90$ & $2.31-2.73$ & $1.50-1.95$ \\
\hline $\mathrm{K}_{2} \mathrm{O}$ & $0.00-0.03$ & $0.00-0.02$ & $0.00-0.03$ & $0.00-0.04$ & $0.01-0.09$ \\
\hline $\mathrm{H}_{2} \mathrm{O}_{\text {(calc.) }}$ & $3.33-3.51$ & $3.25-3.40$ & $3.24-3.33$ & $3.16-3.41$ & $2.96-3.25$ \\
\hline $\mathrm{F}_{2}$ & $0.00-0.26$ & $0.00-0.30$ & $0.00-0.35$ & $0.00-0.42$ & $0.00-0.29$ \\
\hline$-\mathrm{O}=\mathrm{F}_{2}$ & $-0.11-0.00$ & $-0.13-0.00$ & $-0.15-0.00$ & $-0.18-0.00$ & $-0.12-0.00$ \\
\hline $\begin{array}{l}\text { Total } \\
\text { apfu }\end{array}$ & $98.96-100.88$ & $99.25-99.93$ & $98.89-100.37$ & $98.92-100.36$ & $97.44-101.35$ \\
\hline${ }^{x} \mathrm{Na}^{+}$ & $0.78-0.91$ & $0.82-0.93$ & $0.84-0.95$ & $0.76-0.88$ & $0.48-0.62$ \\
\hline${ }^{X_{\mathrm{K}}^{+}}$ & $0.00-0.01$ & 0.00 & $0.00-0.01$ & $0.00-0.01$ & $0.00-0.02$ \\
\hline${ }^{X} \mathrm{Ca}^{2+}$ & $0.00-0.02$ & $0.00-0.05$ & $0.01-0.04$ & $0.02-0.12$ & $0.06-0.17$ \\
\hline${ }^{x} \square$ & $0.08-0.21$ & $0.07-0.14$ & $0.04-0.14$ & $0.07-0.17$ & $0.21-0.46$ \\
\hline$\Sigma X$ & 1.00 & 1.00 & 1.00 & 1.00 & 1.00 \\
\hline${ }^{Y+Z} \mathrm{Al}^{3+}$ & $6.05-6.33$ & $6.01-6.14$ & $5.73-6.12$ & $5.92-6.11$ & $637-6.81$ \\
\hline${ }^{Y+Z} \mathrm{Fe}^{2+}$ & $1.18-1.51$ & $1.17-1.34$ & $1.33-1.64$ & $1.15-1.36$ & $0.79-1.05$ \\
\hline${ }^{Y+Z} \mathrm{Mg}^{2+}$ & $1.31-1.53$ & $1.48-1.64$ & $1.32-1.53$ & $1.50-1.73$ & $1.17-1.44$ \\
\hline${ }^{Y+Z} \mathrm{Ti}^{4+}$ & $0.01-0.04$ & $0.06-0.17$ & $0.05-0.30$ & $0.05-0.18$ & $0.02-0.16$ \\
\hline$\Sigma(Y+Z)$ & 3.00 & 3.00 & 3.00 & 3.00 & 3.00 \\
\hline $\mathrm{B}^{3+}$ & 3.00 & 3.00 & 3.00 & 3.00 & 3.00 \\
\hline${ }^{T} \mathrm{Si}^{4+}$ & $6.02-6.18$ & $6.07-6.17$ & $6.03-6.17$ & $6.00-6.14$ & $5.73-6.00$ \\
\hline${ }^{T} \mathrm{Al}$ & 0.00 & 0.00 & 0.00 & 0.00 & $0.00-0.27$ \\
\hline$\Sigma T^{*}$ & 6.00 & 6.00 & 6.00 & 6.00 & 6.00 \\
\hline $\mathrm{O}^{2-}$ & $27.04-27.21$ & $27.16-27.26$ & $27.10-27.27$ & $27.11-27.28$ & $27.39-27.70$ \\
\hline $\mathrm{OH}^{-}$ & $3.71-3.93$ & $3.65-3.81$ & $3.64-3.89$ & $3.52-3.79$ & $3.29-3.54$ \\
\hline $\mathrm{F}^{-}$ & $0.00-0.14$ & $0.00-0.16$ & $0.00-0.19$ & $0.00-0.22$ & $0.00-0.15$ \\
\hline
\end{tabular}

Notes: * the Si content accepted in the stoichiometric amount of 6 apfu. 
TABLE 2

Average compositions of zoned tourmaline crystals from Rędziny (statistic data)

\begin{tabular}{|c|c|c|c|c|c|c|c|c|c|c|}
\hline & \multicolumn{2}{|l|}{ core } & \multicolumn{2}{|c|}{ mantle 1} & \multicolumn{2}{|c|}{ mantle 2} & \multicolumn{2}{|c|}{ mantle 3} & \multicolumn{2}{|l|}{$\operatorname{rim}$} \\
\hline & wt.\% & $\mathrm{sd}$ & wt.\% & sd & wt.\% & $\mathrm{sd}$ & wt.\% & $\mathrm{sd}$ & wt. $\%$ & sd \\
\hline $\mathrm{SiO}_{2}$ & 36.37 & 0.23 & 36.41 & 0.10 & 36.13 & 0.24 & 36.28 & 0.17 & 35.62 & 0.45 \\
\hline $\mathrm{TiO}_{2}$ & 0.16 & 0.06 & 0.91 & 0.30 & 1.12 & 0.57 & 1.08 & 0.21 & 0.81 & 0.32 \\
\hline $\mathrm{B}_{2} \mathrm{O}_{3 \text { (calc.) }}$ & 10.36 & 0.05 & 10.32 & 0.04 & 10.28 & 0.07 & 10.38 & 0.06 & 10.54 & 0.10 \\
\hline $\mathrm{Al}_{2} \mathrm{O}_{3}$ & 31.39 & 0.35 & 30.54 & 0.29 & 29.94 & 0.76 & 30.40 & 0.32 & 34.96 & 0.82 \\
\hline $\mathrm{FeO}$ & 9.96 & 0.52 & 9.04 & 0.45 & 10.43 & 0.54 & 8.87 & 0.42 & 6.67 & 0.55 \\
\hline $\mathrm{MgO}$ & 5.51 & 0.22 & 6.17 & 0.25 & 5.61 & 0.20 & 6.51 & 0.28 & 5.36 & 0.32 \\
\hline $\mathrm{CaO}$ & 0.04 & 0.03 & 0.14 & 0.11 & 0.12 & 0.04 & 0.33 & 0.13 & 0.65 & 0.16 \\
\hline $\mathrm{Na}_{2} \mathrm{O}$ & 2.68 & 0.10 & 2.66 & 0.12 & 2.71 & 0.10 & 2.55 & 0.12 & 1.79 & 0.09 \\
\hline $\mathrm{K}_{2} \mathrm{O}$ & 0.00 & 0.01 & 0.00 & 0.01 & 0.01 & 0.01 & 0.01 & 0.01 & 0.04 & 0.02 \\
\hline $\mathrm{H}_{2} \mathrm{O}_{\text {(calc.) }}$ & 3.40 & 0.05 & 3.27 & 0.06 & 3.30 & 0.06 & 3.28 & 0.06 & 3.10 & 0.06 \\
\hline $\mathrm{F}_{2}$ & 0.11 & 0.08 & 0.23 & 0.05 & 0.16 & 0.09 & 0.22 & 0.10 & 0.10 & 0.06 \\
\hline$-\mathrm{O}=\mathrm{F}_{2}$ & -0.05 & 0.04 & -0.10 & 0.13 & -0.07 & 0.04 & -0.09 & 0.04 & -0.04 & 0.03 \\
\hline \multirow[t]{2}{*}{ Total } & 99.94 & 0.38 & 99.61 & 0.25 & 99.76 & 0.39 & 99.82 & 0.41 & 99.60 & 0.74 \\
\hline & apfu & $\mathrm{sd}$ & apfu & $\mathrm{sd}$ & apfu & sd & apfu & $\mathrm{sd}$ & apfu & sd \\
\hline${ }^{x} \mathrm{Na}^{+}$ & 0.87 & 0.03 & 0.87 & 0.04 & 0.89 & 0.03 & 0.83 & 0.04 & 0.57 & 0.03 \\
\hline${ }^{x} \mathrm{~K}^{+}$ & 0.00 & 0.00 & 0.00 & 0.00 & 0.00 & 0.00 & 0.00 & 0.00 & 0.01 & 0.00 \\
\hline${ }^{X} \mathrm{Ca}^{2+}$ & 0.01 & 0.01 & 0.03 & 0.02 & 0.02 & 0.01 & 0.06 & 0.02 & 0.11 & 0.03 \\
\hline${ }^{x} \square$ & 0.12 & 0.03 & 0.10 & 0.03 & 0.09 & 0.03 & 0.11 & 0.02 & 0.31 & 0.05 \\
\hline$\Sigma X$ & 1.00 & & 1.00 & & 1.00 & & 1.00 & & 1.00 & \\
\hline${ }^{Y+Z} \mathrm{Al}^{3+}$ & 6.20 & 0.06 & 6.06 & 0.04 & 5.97 & 0.12 & 6.00 & 0.05 & 6.66 & 0.12 \\
\hline${ }^{Y+Z} \mathrm{Fe}^{2+}$ & 1.40 & 0.07 & 1.27 & 0.07 & 1.48 & 0.08 & 1.24 & 0.06 & 0.92 & 0.08 \\
\hline${ }^{Y+Z} \mathrm{Mg}^{2+}$ & 1.38 & 0.06 & 1.55 & 0.06 & 1.42 & 0.05 & 1.62 & 0.07 & 1.32 & 0.07 \\
\hline${ }^{Y+Z} \mathrm{Ti}^{4+}$ & 0.02 & 0.01 & 0.12 & 0.04 & 0.14 & 0.07 & 0.14 & 0.03 & 0.10 & 0.04 \\
\hline$\Sigma(Y+Z)$ & 9.00 & & 9.00 & & 9.00 & & 9.00 & & 9.00 & \\
\hline $\mathrm{B}^{3+}$ & 3.00 & & 3.00 & & 3.00 & & 3.00 & & 3.00 & \\
\hline${ }^{T} \mathrm{Si}^{4+}$ & 6.10 & 0.04 & 6.13 & 0.03 & 6.11 & 0.03 & 6.07 & 0.03 & 5.87 & 0.05 \\
\hline${ }^{T} \mathrm{Al}$ & 0.00 & & 0.00 & & 0.00 & & 0.00 & & 0.13 & \\
\hline$\Sigma T$ & 6.00 & & 6.00 & & 6.00 & & 6.00 & & 6.00 & \\
\hline $\mathrm{O}^{2-}$ & 27.13 & 0.05 & 27.21 & 0.03 & 27.19 & 0.05 & 27.22 & 0.04 & 27.54 & 0.06 \\
\hline $\mathrm{OH}^{-}$ & 3.81 & 0.06 & 3.67 & 0.07 & 3.73 & 0.06 & 3.67 & 0.07 & 3.41 & 0.06 \\
\hline $\mathrm{F}^{-}$ & 0.06 & 0.05 & 0.12 & 0.07 & 0.09 & 0.05 & 0.12 & 0.05 & 0.05 & 0.03 \\
\hline
\end{tabular}



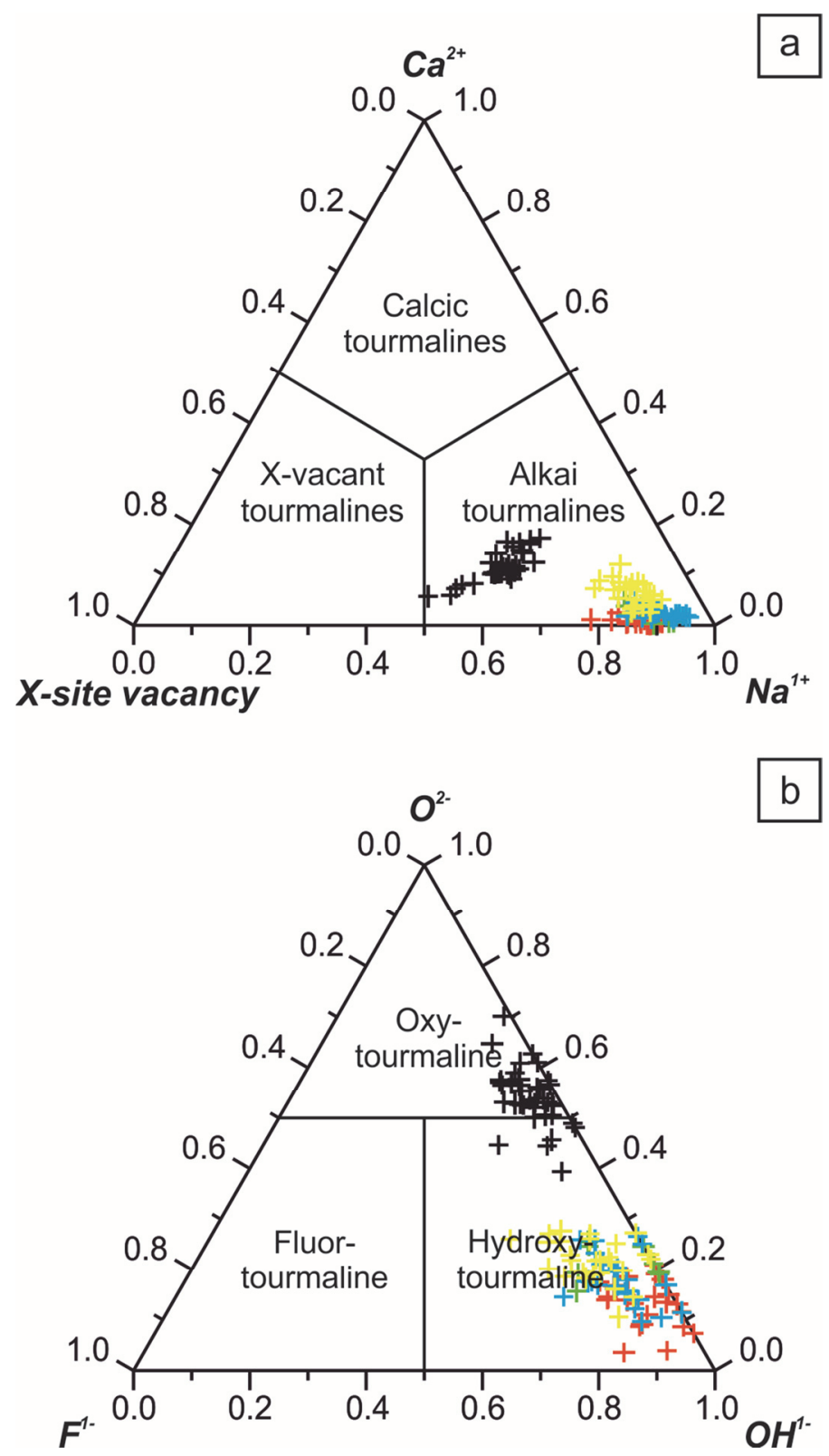

Fig. 5. Classification of tourmalines from Rędziny in terms of (a) $X$-site occupants and (b) W-site occupants. Symbols as in Fig. 4. 

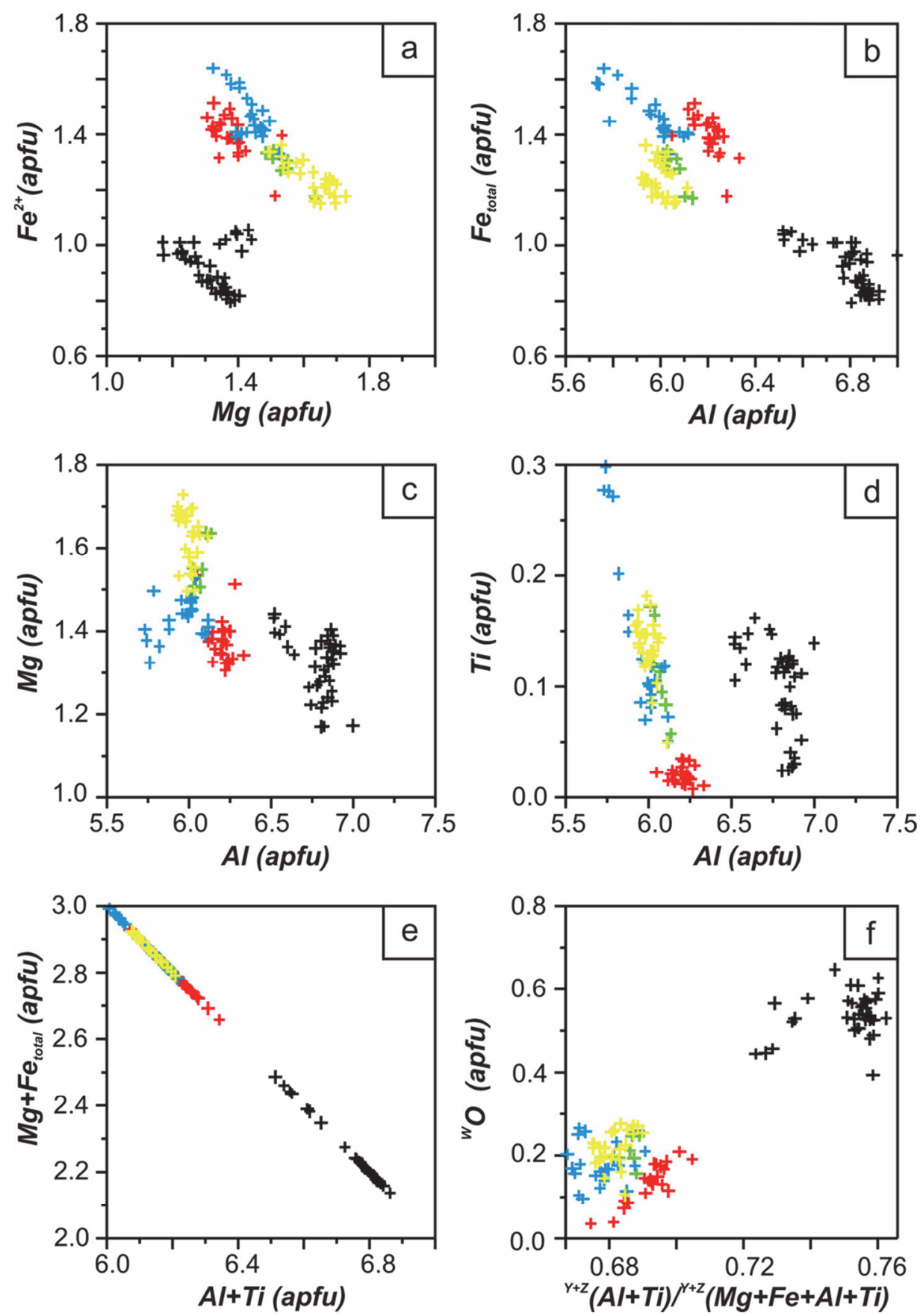

Fig. 6. Compositional relationships in the Rędziny tourmalines. (a) $\mathrm{Fe}^{2+} \mathrm{vs} \mathrm{Mg}$, (b) $\mathrm{Fe}_{\text {tot }} \mathrm{vs} \mathrm{Al}$ covariation, (c) $\mathrm{Mg}$ vs $\mathrm{Al}$, (d) $\mathrm{Ti}$ vs $\mathrm{Al}$, (e) $\mathrm{Mg}+\mathrm{Fe}_{\text {tot }}$ vs $\mathrm{Al}+\mathrm{Ti}$, (f) ${ }^{W} \mathrm{O}$ vs ${ }^{Y+Z}(\mathrm{Al}+\mathrm{Ti}){ }^{Y+Z}(\mathrm{Al}+\mathrm{Mg}+\mathrm{Fe}+\mathrm{Ti})$. Symbols as in Fig. 4. 
In the tourmaline, $\mathrm{O}^{2-}$ partly substitutes for monovalent $\mathrm{OH}^{-}$and $\mathrm{F}^{-}$anions in the anionic $W$ site. The degree of substitution is, however, subordinate in the core and mantle tourmaline, and dominant only in the rim tourmaline. The presence of $\mathrm{O}^{2-}$ at the $W$ site of the tourmaline structure can only be satisfied for $3 \mathrm{Al}$ or $2 \mathrm{Al}+\mathrm{Mg}$ local arrangements of the $Y$-octahedra triad (Hawthorne 1996). This requirement can be fulfilled only by $\mathrm{Mg}\left(\mathrm{Fe}^{2+}\right)-\mathrm{Al}$ disorder induced through the substitution ${ }^{W}(\mathrm{OH})^{-}+{ }^{Y} \mathrm{Mg}_{2}+{ }^{Z} \mathrm{Al} \leftrightarrow{ }^{W} \mathrm{O}^{2-}+{ }^{Y} \mathrm{Al}_{2}+{ }^{Z} \mathrm{Mg}$ and the $\mathrm{O}^{2-}$ content at the $W$ site being equal to the smaller of the two quantities ${ }^{Y} \mathrm{Al} / 2$ or ${ }^{Z} \mathrm{Mg}$. The equation, along with assumed uvite-type and foitite-type substitutions, explaining the presence of $\mathrm{Ca}$ and vacancy at the $X$ site, provides an opportunity to evaluate predicted $\mathrm{Al}-\mathrm{Mg}\left(\mathrm{Fe}^{2+}\right)$ disorder and give approximate average formulae for the tourmalines. These are as given immediately below with variants corresponding to $\mathrm{Mg}$ - $\mathrm{Al}$ disordering:

1. Blue core tourmaline (schorl/dravite):

$\left(\mathrm{Na}_{0.87} \square_{0.12} \mathrm{Ca}_{0.01}\right)_{\Sigma 1}\left(\mathrm{Fe}^{2+}{ }_{1.40} \mathrm{Mg}_{1.22} \mathrm{Al}_{0.36} \mathrm{Ti}_{0.02}\right)_{\Sigma 3}\left(\mathrm{Al}_{5.84} \mathrm{Mg}_{0.16}\right)_{\Sigma 6} \mathrm{~B}_{3} \mathrm{Si}_{6} \mathrm{O}_{27}(\mathrm{OH})_{3}\left[(\mathrm{OH})_{0.81} \mathrm{O}_{0.13} \mathrm{~F}\right.$ $0.06)_{\Sigma 1}$

2. Olive to brown mantle tourmaline (schorl/dravite):

a. $\left(\mathrm{Na}_{0.87} \square_{0.10} \mathrm{Ca}_{0.03}\right)_{\Sigma 1}\left(\mathrm{Fe}^{2+}{ }_{1.27} \mathrm{Mg}_{1.21} \mathrm{Al}_{0.40} \mathrm{Ti}_{0.12}\right)_{\Sigma 3}\left(\mathrm{Al}_{5.66} \mathrm{Mg}_{0.34}\right)_{\Sigma 6} \mathrm{~B}_{3} \mathrm{Si}_{6} \mathrm{O}_{27}(\mathrm{OH})_{3}\left[(\mathrm{OH})_{0.67}\right.$ $\left.\mathrm{O}_{0.21} \mathrm{~F}_{012}\right)_{\Sigma 1}$

b. $\left(\mathrm{Na}_{0.89} \square_{0.09} \mathrm{Ca}_{0.02}\right)_{\Sigma 1}\left(\mathrm{Fe}^{2+}{ }_{1.48} \mathrm{Mg}_{1.05} \mathrm{Al}_{0.33} \mathrm{Ti}_{0.14}\right)_{\Sigma 3}\left(\mathrm{Al}_{5.63} \mathrm{Mg}_{0.37}\right)_{\Sigma 6} \mathrm{~B}_{3} \mathrm{Si}_{6} \mathrm{O}_{27}(\mathrm{OH})_{3}\left[(\mathrm{OH})_{0.73}\right.$ $\left.\mathrm{O}_{0.19} \mathrm{~F}_{0.09}\right)_{\Sigma 1}$

c. $\left(\mathrm{Na}_{0.83} \square_{0.11} \mathrm{Ca}_{0.06}\right)_{\Sigma 1}\left(\mathrm{Fe}^{2+}{ }_{1.24} \mathrm{Mg}_{1.21} \mathrm{Al}_{0.41} \mathrm{Ti}_{0.14}\right)_{\Sigma 3}\left(\mathrm{Al}_{5.59} \mathrm{Mg}_{0.41}\right)_{\Sigma 6} \mathrm{~B}_{3} \mathrm{Si}_{6} \mathrm{O}_{27}(\mathrm{OH})_{3}\left[(\mathrm{OH})_{0.67}\right.$ $\left.\mathrm{O}_{0.22} \mathrm{~F}_{0.12(2)}\right)_{\Sigma 1}$

3. Light green rim tourmaline (oxy-schorl/oxy-dravite):

$\left(\mathrm{Na}_{0.57} \square_{0.31} \mathrm{Ca}_{0.11} \mathrm{~K}_{0.01}\right)_{\Sigma 1}\left(\mathrm{Fe}^{2+}{ }_{0.92} \mathrm{Mg}_{0.67} \mathrm{Al}_{1.31} \mathrm{Ti}_{0.10}\right)_{\Sigma 3}\left(\mathrm{Al}_{5.35} \mathrm{Mg}_{0.65}\right)_{\Sigma 6} \mathrm{~B}_{3}\left(\mathrm{Si}_{5.87} \mathrm{Al}_{0.13}\right) \mathrm{O}_{27}(\mathrm{OH})_{3}$ $\left[(\mathrm{OH})_{0.41} \mathrm{O}_{0.54} \mathrm{~F}_{0.05}\right)_{\Sigma 1}$

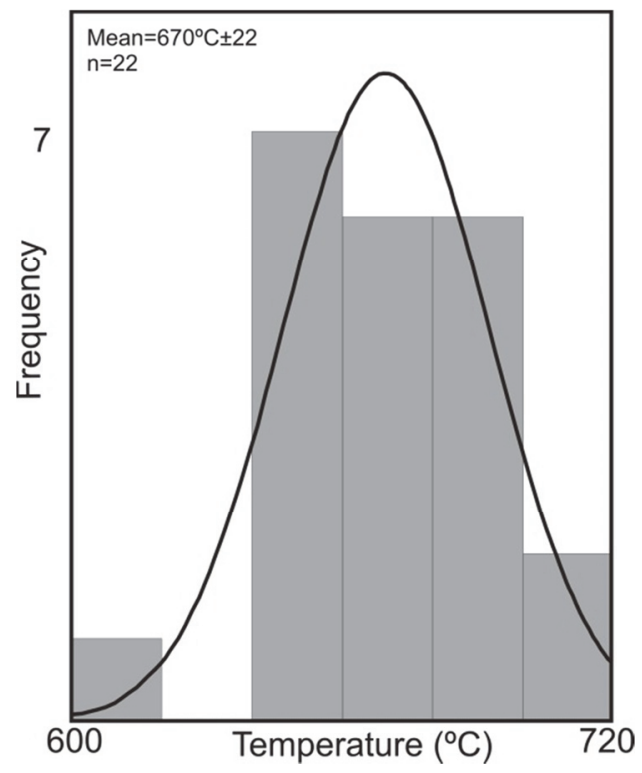

Fig. 7. Histogram of the contact-metamorphism temperatures obtained using the Ti-in-biotite method of Henry et al. (2005). 
In the Fe-Mg- $\mathrm{Al}_{\text {total }}$ system of Henry and Guidotti (1985), the compositions of the core and mantle tourmaline plot in the field of tourmalines associated with metapelites and metapsammites not coexisting with an Al-saturating phase (Fig. 7). The compositional trends in successive core and mantle (sub)zones relate mainly to the $\mathrm{Fe} \leftrightarrow \mathrm{Mg}$ and $\mathrm{Fe} \leftrightarrow \mathrm{Al}$ replacements and mark progressive $\mathrm{Mg}$ enrichment with crystallization. The rim tourmaline has a completely different signature, mainly due to anomalously high $\mathrm{Al}$ contents, and plots in the area corresponding to tourmalines originated from metapelites and metapsammites coexisting with an Al-saturating phase.

\section{Estimation of temperature of contact metamorphism}

Based on the structural position of the dark mica and its relationship to tourmaline, the Ti-in-biotite geothermometer was used to estimate the crystallization temperature of tourmaline rims growing coevally with large transversal flakes of the dark mica. This method can be used for peraluminous metapelites which contain graphite \pm rutile \pm ilmenite (Henry et al. 2005). As the dark mica associated with the Rędziny tourmaline has $\mathrm{Ti}$ contents ranging from 0.263 to $0.435 \mathrm{apfu}, \mathrm{Si}$ in range 5.17-5.37 apfu and $\mathrm{Mg} /(\mathrm{Mg}+\mathrm{Fe})$ in

TABLE 3

Ti (apfu), $\mathrm{X}_{\mathrm{Mg}}$ and obtained temperatures for biotite from the Rędziny hornfels.

\begin{tabular}{lll}
\hline $\mathrm{Ti}$ & $\mathrm{X}_{\mathrm{Mg}}$ & $\mathrm{T}\left({ }^{\circ} \mathrm{C}\right)$ \\
\hline 0.429 & 0.412 & 701 \\
0.399 & 0.411 & 691 \\
0.355 & 0.402 & 672 \\
0.359 & 0.411 & 675 \\
0.299 & 0.431 & 648 \\
0.38 & 0.446 & 688 \\
0.435 & 0.445 & 708 \\
0.307 & 0.466 & 659 \\
0.319 & 0.436 & 660 \\
0.345 & 0.426 & 671 \\
0.344 & 0.416 & 669 \\
0.345 & 0.408 & 668 \\
0.318 & 0.462 & 663 \\
0.288 & 0.449 & 645 \\
0.23 & 0.474 & 610 \\
0.285 & 0.475 & 648 \\
0.3 & 0.472 & 656 \\
0.263 & 0.533 & 647 \\
0.371 & 0.441 & 684 \\
0.366 & 0.444 & 682 \\
0.397 & 0.418 & 691 \\
0.419 & 0.411 & 698 \\
\hline
\end{tabular}


range 0.401-0.533, it can be classified as siderophyllite. Temperatures based on the $\mathrm{Ti}$ (apfu) and Mg-number (Table 3; Fig. 8.) range from $610^{\circ} \mathrm{C}$ to $701^{\circ} \mathrm{C}\left(\sim 670^{\circ} \mathrm{C}\right.$ mean; $\mathrm{n}=$ 22). The occurrence of andalusite and the lack of sillimanite imply that the rock must have been formed within the andalusite stability field. Thus, the estimated temperatures seem slightly too high. Neither 701 nor $670^{\circ} \mathrm{C}$ could have been experienced by the rock, and not more than $610-650^{\circ} \mathrm{C}$ seems possible for the Rędziny hornfels. The imperfection of the temperature calculation may well reflect pressure boundary conditions. The pressure of metamorphism was almost certainly below 4 kbar (presumably 2-3 kbar). The application of this calibration of the Ti-in-biotite geothermometer is accurate only for pressures ranging from 4-6kbar (Henry et al. 2005).

\section{Discussion and concluding remarks}

The compositional zoning in tourmaline from the hornfelses in the Rędziny quarry shows two main stages of crystallization. Core and mantle tourmaline can be related to the first regional metamorphic event. Unambiguously, rim tourmaline grew in the much different chemical environment; the evident enrichment in $\mathrm{Al}$ and subsequent depletion in $\mathrm{Si}$ is a typical substitution feature of these outermost zones. The enrichment in Al indicates the growth of the rim tourmaline in the presence of an Al-saturating phase, in this case, andalusite.

In accord with geological evidence, the growth of the core tourmaline can be related to the intermediate P-T metamorphic event, whereas the mantle zone probably represents the lower $\mathrm{P}$, higher $\mathrm{T}$ event associated with the extensional collapse of the orogen. The fluctuation of $\mathrm{Mg}$ and $\mathrm{Fe}$ from core to mantle confirms the growth of both zones by increasing temperature. A similar trend can be inferred from the progressive increase in $\mathrm{Ca}$ and $\mathrm{Ti}$, probably resulting from progressive plagioclase and ilmenite decomposition. The outermost zone tourmaline grew in the Al-enriched environment established in the contact aureole of the Karkonosze Granite. The enrichment in $\mathrm{Ca}$ in the rims also confirms the growth of this tourmaline during contact metamorphism (e.g. Bröcker, Franz 2000).

Henry and Guidotti (1985) showed that almost any detrital core tends to be preserved by increasing temperature in fine-grade pelitic sediments. By transition from greenschist to amphibolite facies, the tourmaline will have a much greater proportion of metamorphic overgrowth to detrital core (Frey 1969 fide Henry, Guidotti 1985). The Rędziny hornfels experienced a multistage metamorphic history during which the P-T conditions reached at least lower amphibolite facies conditions. Thus, it is assumed that the zoning revealed in the tourmaline expresses consecutive stages of its metamorphic history. Moreover, the chemical composition of all the measured cores is similar, whereas detrital cores should be expected to differ from each other, indicating multiple sedimentary sources (e.g. granites, pegmatites, metamorphic rocks). Thus, the tourmalines are interpreted to be of entirely metamorphic origin.

Notably, the Rędziny tourmaline does not reveal significant schörl end-member enrichment in the outermost overgrowths as, e.g. do the tourmalines from the northern envelope of the Karkonosze Granite of the Izera region (Słaby, Kozłowski 2005). Graniterelated hydrothermal fluids unambiguously buffered the chemical composition of outer zones of those tourmalines, whereas it was obviously not the case with the tourmalines 
from Rędziny. Also, the host rock is different at both locations, a factor which could have influenced the development of tourmaline during the emplacement of the Karkonosze Granite and the associated contact metamorphism coupled with hydrothermal alteration.

The results of Ti-in-biotite thermometry, if accurate, show that the T-peak conditions during contact metamorphism reached $\sim 670^{\circ} \mathrm{C}$. Although the Ti-in-biotite method as a single-mineral geothermometer was calibrated for slightly higher-pressure conditions, the method can also be used for very low-pressure rocks. In such cases, the results obtained can suggest slightly higher temperatures and must be treated with caution. For instance, Henry et al. (2005) showed that this thermometer applied to biotite data of Pattison et al. (2002) indicated a temperature $\sim 16^{\circ} \mathrm{C}$ higher than that calculated using other geothermometers. However, when the method is used as a complementary one, the results obtained can be considered as accurate with a degree of confidence.

Staby et al. (2008) calculated the temperature of the Karkonosze granitic magma in the range $697-736^{\circ} \mathrm{C}$ based on $\mathrm{Zr}$ saturation. Mochnacka et al. (2008) estimated the temperature of contact metamorphism in the Budniki region, also in the eastern envelope of the Karkonosze Granite, at $473-635^{\circ} \mathrm{C}$. Pieczka et al. (2009) suggested an initial crystallization of arsenopyrite and pyrrhotite in an ore assemblage from Rędziny at temperatures below $550^{\circ} \mathrm{C}$, whereas Mochnacka et al. (2001) proposed the crystallization temperature of early cassiterite to be $412^{\circ} \mathrm{C}$ at pressures around 0.8-0.9 kbar. Additionally, Słaby and Martin (2008) estimated the minimum pressure for the Karkonosze Granite emplacement at 1-2 kbar and 1-3 kbar for the equigranular- and porphyrytic varieties of the hybrid quartz diorites-granodiorites, respectively. These results corroborate our temperature calculations for rocks located very near the contact of the Karkonosze Pluton. The peak temperature lower than $670^{\circ} \mathrm{C}$, and the lack of sillimanite and garnet in the related paragenesis, support the conclusion that pressures did not exceed $\sim 2-3$ kbars corresponding to the $\mathrm{C} 1$ bathozone (Carmichael 1978) or the P1 bathozone of Pattison and Tracy (1991) and Pattison (2001). Pattison (2001) also argued that the $\mathrm{Al}_{2} \mathrm{SiO}_{5}$ "triple point" is not stable and can be moved towards higher P-T values in so-called common metapelites. In light of this, our temperature estimate fits well to Pattison's P1 bathozone. Moreover, the observed paragenesis, containing andalusite and biotite, and lacking or almost lacking sillimanite, garnet and cordierite, is known from several contact aureoles worldwide and is characteristic of LP-HT rocks closely abutting intrusions, e.g. the Bugaboo aureole (Pattison et al. 2002).

Acknowledgements. We are grateful to R. Shimizu and an anonymous reviewer for their constructive reviews. R.F. Martin is thanked for constructive comments improving this manuscript. L. Jeżak is thanked for her assistance with the EMP analyses. This research was supported by AGH University of Science and Technology grant no. 11.11.140.158.

\section{References}

Berg, G. (1912). Die krystallinen Schiefer des östlichen Riesengebirges. Abhandlungen des Preussischen Geologischen Landesamtes, 28, 1-188. Berlin.

Bröcker, M., \& Franz, L. (2000). The contact aureole on Tinos (Cyclades, Greece). tourmaline-biotite geothermometry and Rb-Sr geochronology. Mineralogy and Petrology, 70, 257-283. 
Carmichael, D. M. (1978). Metamorphic bathozones and bathograds. A measure of the depth of post metamorphic uplift and erosion on the regional scale. American Journal of Science, 278, 769-797.

Chaloupský, J. (1965). Metamorphic development of the Krkonose crystalline complex. Krystalinikum, 3, 31-54.

Chaloupský, J. (ed.) (1989). Geology of the Krkonose and Jizerske hory Mts. Ústřední ústav geologický, 288 pp, Praha. (in Czech, with English summary).

da Fonseca-Zang, W. A., Zang, J. W. \& Hofmaister, W. (2008). The Ti-influence on the tourmaline color. Journal of the Brazilian Chemical Society, 19/6, 1186-1192.

Frey, M. (1969). Die metamorphose des Keupers vom Tafeljura bis zum Lukmanier-Gebeit (Veranderungen tonigmergeliger Geteine von Bereich der Diagenese bis zur stauralith-zone). Beitraege zur Geologishen Karte der Schweiz, 137, 1-160.

Hawthorne, F. C. (1996). Structural mechanism for light-element variations in tourmaline. Canadian Mineralogist. $34,123-132$.

Hawthorne, F. C., \& Henry, D. J. (1999). Classification of the minerals of the tourmaline group. European Journal of Mineralogy, 11, 201-215. DOI: 10.1127/ejm/11/2/0201.

Henry, D. J., \& Dutrow, B. L. (1996). Metamorphic tourmaline and its petrological applications. In. Grew E.S., Anovitz L.M. (eds) Boron: mineralogy, petrology and geochemistry. Reviews in Mineralogy, 33, 503-557.

Henry, D. J., \& Guidotti, C. V. (1985). Tourmaline as a petrogenetic indicator mineral. an example from the staurolite-grade metapelites of NW Maine. American Mineralogist, 70, 1-15.

Henry, D. J., Guidotti, C. V., \& Thomson, J. A. (2005). The Ti-saturation for low-to-medium pressure metapelitic biotites. Implications for geothermometry and Ti-substitution mechanisms. American Mineralogist, 90, 316328. DOI: $10.2138 / \mathrm{am} .2005 .1498$

Jeřábek, P., Konopásek, J., \& Žáčková, E. (2016). Two-stage exhumation of subducted Saxothuringian continental crust records underplating in the subduction channel and collisional forced folding (Krkonoše-Jizera Mts., Bohemian Massif). Journal of Structural Geology, 89, 214-229. DOI: http://dx.doi.org/10.1016/j.jsg.2016.06.008.

Kodym, O., \& Svoboda, J. (1948). Kaledonská přikrovová stavba Krkonoš a Jizerských hor. Sbornik Státnh́o Geologického Ústavu Republiky Československé, 15, 109-160, Praha. (in Czech).

Kryza, R., \& Mazur, S. (1995). Contrasting metamorphic paths in the SE part of the Karkonosze-Izera block (Western Sudetes, SW Poland). Neues Jahrbuch für Mineralogie, Abhandlungen, 169, 157-192.

Kryza, R., Schaltegger, U., Oberc-Dziedzic, T., Pin, C., \& Ovtcharova, M. (2014). Geochronology of a composite granitoid pluton. a high-precision ID-TIMS U-Pb zircon study of the Variscan Karkonosze Granite (SW Poland). International Journal of Earth Sciences, 103, 683-696. DOI 10.1007/s00531-013-0995-0

Machowiak, K., \& Armstrong, R. (2007). SHRIMP U-Pb zircon age of the Karkonosze granite. Mineralogia Polonica-Special Papers, 31, 193-196.

Majka, J., Mazur, S., Kośmińska, K., Dudek, K., \& Klonowska, I. (2016). Pressure-temperature estimates of the blueschists from the Kopina Mt., northern Bohemian Massif, Poland - Constraints on subduction of the Saxothuringian continental margin. European Journal of Mineralogy, 28(6), 1047-1057. DOI: 10.1127/ejm/2016/0028-2601.

Maška, M. (1954). K Tektonicke Analyse Krystalinika, Knihovna Ústředního ústavu geologického, 258 pp., Praha. (in Czech).

Mazur, S. (1995). Structural and metamorphic evolution of the country rocks at the eastern contact of the Karkonosze granite in the southern Rudawy Janowickie Mts and Lasocki Range. Geologia Sudetica, 29, 3198 (in Polish, English summary).

Mazur, S., \& Aleksandrowski, P. (2001). The Teplá(?)/Saxothuringian suture in the Karkonosze-Izera massif, Western Sudetes, Central European Variscides. International Journal of Earth Sciences, 90, 341-360. DOI: $10.1007 / \mathrm{s} 005310000$

Mazur, S., \& Kryza, R. (1996). Superimposed compressional and extensional tectonics in the Karkonosze-Izera Block, NE Bohemian Massif. In. Oncken, O., \& Janssen, C. (eds.), Basement Tectonics, 11, Europe and Other Regions. Potsdam, Kluwer, Dordrecht, 51-66.

Mochnacka, K., Oberc-Dziedzic, T., Mayer, W., \& Pieczka, A. (2008). Ti remobilization and sulphide/sulphoarsenide mineralization in amphibolites: effect of granite intrusion (the Karkonosze-Izera Massif, SW Poland). Geological Quarterly, 52(4), 349-368.

Mochnacka, K., Pieczka, A., Gołębiowska, B., \& Kozłowski, A. (2001). Cassiterite from Rędziny and its relationship to the tin-bearing schist of Izera area (SW Poland). [in.] A. Piestrzyński et al. (eds.). Mineral Deposits at the Beginning of the $21^{\text {st }}$ Century. Balkema Rotterdam, 457-460. 
Oberc, J. (1960). Eastern Karkonosze tectonics and their position in the Sudeten Structures. Acta Geologica Polonica, 10(1), 1-48, (in Polish, with English summary).

Oberc-Dziedzic, T., Kryza, R., Mochnacka, K., \& Larionov, A. (2010). Ordovician passive continental margin magmatism in the Central-European Variscides. U-Pb zircon data from the SE part of the Karkonosze-Izera Massif, Sudetes, SW Poland. International Journal of Earth Sciences, 99(1), 27-46. DOI: 10.1007/s00531008-0382-4.

Oliver, G. J. H., Corfu, F., \& Krough, T. E. (1993). U-Pb ages from SW Poland: evidence for a Caledonian suture zone between Baltica and Gondwana. Journal of the Geological Society of London, 150, 355-369.

Pattison, D. R. M. (2001). Instability of Al2SiO5 "triple point" assemblages in muscovite+biotite+quartz bearing metapelites, with implications. American Mineralogist, 86, 1414-1424.

Pattison, D. R. M., \& Tracy, R. J. (1991). Phase equilibria and thermobarometry of metapelites. In. D.M. Kerrick, Ed., Contact metamorphism, Reviews in Mineralogy, 26, 105-206.

Pattison, D. R. M., Spear, F. S., Debuhr, C. L., Cheney, J. T., \& Guidotti, C. V. (2002). Thermodynamic modeling of the reaction muscovite + cordierite $\rightarrow \mathrm{Al}_{2} \mathrm{SiO}_{5}+$ biotite + quartz $+\mathrm{H}_{2} \mathrm{O}$ : constraints from natural assemblages and implications for the metapelitic petrogenetic grid. Journal of metamorphic Geology, 20, 99-118. DOI: 10.1046/j.0263-4929.2001.356.356.x.

Pirajno, F. (1992). Hydrothermal mineral deposits. Springer Verlag, Berlin.

Pieczka, A., \& Kraczka, J. (2004). Oxidized tourmalines - a combined chemical, XRD and Mössbauer study. European Journal of Mineralogy, 16(2), 309-321. DOI: 10.1127/0935-1221/2004/0016-0309.

Pieczka, A., Gołębiowska, B., \& Parafiniuk, J. (2009). Conditions of formation of polymetallic mineralization in the eastern envelope of the Karkonosze granite. the case of Rędziny, southwestern Poland. Canadian Mineralogist, 47(4), 765-786. DOI: 10.3749/canmin.47.4.765.

Pouchou, J. L., \& Pichor, F. (1985). "PAP" (phi-rho-z) procedure for improved quantitative microanalysis. In. Armstrong, J.T. (ed) Microbeam Analysis. San Francisco Press, San Francisco, 104-106.

Seston, R., Winchester, J. A., Piasecki, M. A. J., Crowley, Q. G., \& Floyd, P. A. (2000). A structural model for the western-central Sudetes. a deformed stack of Variscan thrust sheets. Journal of the Geological Society, London, 157, 1155-1167. DOI: https://doi.org/10.1144/jgs.157.6.1155.

Słaby, E., \& Kozłowski, A. (2005). Composistion of tourmalines from tin-tungsten-bearing country rock of the Variscan Karkonosze granitoid - a record of the wall rock and hydrothermal fluid interaction. Neues Jahrbuch für Mineralogie - Abhandlungen, 181, 245-263. DOI: 10.1127/0077-7757/2005/0020.

Słaby, E., Götze, J., Wörner, G., Simon, K., Wrzalik, R., \& Śmigielski, M. (2008). K-feldspar phenocrysts in microgranular magmatic enclaves. a cathodoluminescence and geochemical study of crystal growth as a marker of magma mingling dynamics. Lithos, 105(1), 85-97. DOI: https://doi.org/10.1016/ j.lithos.2008.02.006

Słaby, E., \& Martin, H. (2008). Mafic and felsic magma interaction in granites: the Hercynian Karkonosze Pluton (Sudetes, Bohemian Massif). Journal of Petrology,49(2), 353-391. DOI: https://doi.org/10.1093/ petrology/egm085.

Szałamacha, M., \& Szałamacha, J. (1968). The metamorphic series of the Karkonosze-Izera Mountains Block. Biuletyn Instytutu Geologicznego, 222, 33-76, (in Polish, with English summary).

Teisseyre, J. H. (1971). On the age and sequence of beds in the metamorphic rocks of the Rudawy Janowickie range and Lasocki Ridge. Geologia Sudetica, 5, 165-210, (in Polish, with English summary).

Teisseyre, J. H. (1973). Metamorphic rocks of the Rudawy Janowickie and Lasocki Grzbiet ranges. Geologia Sudetica, 8, 7-120, (in Polish, with English summary).

Winkler, H. G. F. (1979). Petrogenesis of metamorphic rocks, $5^{\text {th }}$ ed. Springer-Verlag, New York-HeidelbergBerlin, $348 \mathrm{pp}$.

Žáčková, E., Konopásek, J. P. Jeřábek, P., Finger, F. J., \& Košler, J. (2010). Early Carboniferous blueschist facies metamorphism in metapelites of the West Sudetes (northern Saxothuringian Domain, Bohemian Massif). Journal of Metamorphic Geology, 28, 361-379. DOI: 10.1111/j.1525-1314.2010.00869.x.

Žák, J., Verner, K., Sláma, J., Kachlík, V., \& Chlupáčová, M. (2013). Multistage magma emplacement and progressive strain accumulation in the shallow-level Krkonoše-Jizera plutonic complex, Bohemian Massif. Tectonics, 32, 1493-1512. DOI: 10.1002/tect.20088. 